\title{
Influence of Entrepreneurial Innovation on Sustainable Solid: Waste Recycling in Abuja, Nigeria
}

\author{
Emmanuel Kalu Agbaeze', Sylvester Abomeh Ofobruku²*, Benjamin Ibe Chukwu \\ ${ }^{1}$ Department of Management, Faculty of Business Administration, University of Nigeria, Enugu Campus, Enugu, P. O. B. 3236 , \\ Enugu, Nigeria \\ 2 Department of Business Studies, Faculty of Humanities, Social and Management Sciences. Edwin Clark University, Kiagbodo, \\ P. O. B. 101, Ughelli, Delta, Nigeria \\ *Corresponding author, e-mail: ufomaeliz@yahoo.com
}

Received: 03 June 2018, Accepted: 12 March 2020, Published online: 14 August 2020

\begin{abstract}
One of the most serious challenges that city dwellers face in a developing nation is unsatisfactory solid waste management. This research investigates the impact of entrepreneurial innovation in solid waste recycling capacity in Abuja, federal capital city of Nigeria. The study employs a survey approach entailing the use of questionnaire for primary data collection. The data collected were analysed using a regression statistical technique. The findings of the study reveal that entrepreneurial activities can be used to enhance competencies in sustainable solid waste management in Abuja, Nigeria. Specifically, we found that entrepreneurial innovation has a significant positive effect on solid waste recycling capacity $(p<0.01)$. The study concludes that entrepreneurial innovation will encourage efficiency and effectiveness in solid waste recycling practices in Abuja, Nigeria. The study, therefore, recommends that the government should put in place structures that encourage entrepreneurial innovation in solid management so as to enhance the sustainable solid waste recycling capacity in Abuja, Nigeria. Solid waste recycling has long been thought of as playing an important role in solid waste management. This research affirms that entrepreneurial innovation would aid the improvement of the solid waste recycling capacity thereby optimising the chances of achieving sustainable solid waste management in Abuja, Nigeria. Currently there is a paucity of studies that examine the effects of entrepreneurial innovation specifically on solid waste recycling and sustainable development in Abuja, Nigeria. This study contributes an important additional dimension in the search for sustainable solid waste management in Abuja, Nigeria.
\end{abstract}

Keywords

entrepreneurship, innovation, solid waste, waste recycling, sustainability, Abuja

\section{Introduction}

All over the world entrepreneurial development has remained an important tool in the overall strategies for the growth and development of national economy. Globally entrepreneurial development in most developed and developing economies of the world has enabled nations to establish enterprise, which has provided products and services required by the public (Schendel and Hitt, 2007; Short et al., 2009; Wang and Rajagopalan, 2015). Entrepreneurial activities among others involve innovation and the establishment of new ventures, which constitute the engine for most economic growth (Julian and Ahmed, 2012; Moghavvemi and Mohd-Salleh, 2014; Shook and Bratianu, 2010). Entrepreneurial activities form an essential component of the development process, an integral part of the socio-economic transformation process. Entrepreneurial actions are purposefully geared towards, promoting innovation and economic activities that are directed at the production of goods/services and distribution of wealth (Shirokova et al., 2016; Szirmai et al., 2011; Toma et al., 2014).

A survey conducted by United Nations Development Programme on 151 cities around the world, revealed that one of the most serious problems that city dwellers are currently facing is unsatisfactory solid waste management (Mane, 2015; McNeil and Kerwin, 1998, Ofobruku et al., 2016). Furthermore, in the four-country study carried out by the African Development Bank on solid waste management options for Africa, the study revealed the existence of a general lack of sustainable initiatives to manage and minimize waste by the government in the countries investigated (Palczynski, 2002). In response to the challenge of solid waste, nations have embarked upon holistic reforms by managing solid waste through the involvement 
of entrepreneurs. Although the cooperation between the government and entrepreneurs in solid waste management work well in several developing nations such as India or Sri Lanka just to mention two, the same cannot be said of Nigeria where heaps of garbage littered the streets and drains of most big cities (Ezeah and Roberts, 2014; Mbah and Nzeadibe, 2017; Umaru, 2015).

Currently, the Nigerian federal capital city (Abuja) is faced with the challenge of managing the constantly growing huge volumes of solid waste generated by the large population, with no visible facilities for solid waste recycling (Ayuba et al., 2013; Obia, 2016). More so, an attempt to address the snag of solid waste in Nigeria necessitated the inclusion of an important objective in Nigeria's vision 20:20:20 and goal number four goal of the country's National Transformation Agenda, which was to provide an appropriate and holistic response to the issue of environmental degradation (Federal Government of Nigeria, 2012). Several studies have since shown that the challenge of solid waste management has just minimally improved in Nigeria (Emelumadu et al., 2016; Federal Government of Nigeria, 2012; Igoni and Harry, 2017; Ofobruku and Ezeah, 2019). Therefore, the need to investigate entrepreneurial innovation activities as it affects sustainable solid waste recycling in Abuja, Nigeria becomes imperative. The reason Abuja was chosen for this study, is that Abuja is the federal capital of Nigeria and it is a model for setting the strategy for solid waste management best practice for other cities in Nigeria.

\section{Literature review and hypothesis}

\subsection{Concept of entrepreneurial innovation}

The planning of knowledge from the well-known field to a less familiar one is central to innovativeness ( $\AA$ stebro and Michela, 2005). Innovation stands for the use of new practices in social, cultural and administrative environments and it is defined in the simplest sense as the transformation of knowledge for human benefit (Elçi, 2007). Innovation is also defined as finding different and effective solutions to situations and problems by approaching them with an alternative viewpoint. According to Lunati (2010), innovation as a term is used as referring the skill to convert an idea to an applicable process (Üçdogruk, 2006). Innovativeness, on the other hand, reflects the process of utilizing knowledge and ideas in such a way that it produces beneficial outcomes for the society.

Acs and Szerb (2007) noted that entrepreneurship revolves around innovation, designed to grasp the existing opportunities in the environment, with the choice to commercialize them by initiating the production of goods or services. Scholars like: Adebayo (2015), Toma et al. (2014), states that, fundamentally, innovation has to do with changes that lead to improvement in the quality and capacity of products/ services as well as methods of doing things. Innovation is dynamic and creates new things or better methods of doing things out of the present process.

With the assistance of innovation, the entrepreneur presents new production techniques, new commodities, improves on existing ones, and design new techniques of management. These skills are what the entrepreneur takes into a business venture. Therefore, it can be asserted that the term entrepreneurship innovation entails the systematic coordination of complex operational activities for solving societal difficulties while making some a profit in the process. The concept of innovation in this study consist of the Product/service improvement, which concerns the introduction or modification of new or improved products, process innovation that refers to the introduction of new or improved processes and system innovation, which relates to the introduction of changes in the marketing structure of the entrepreneurs.

\subsection{Solid waste recycling}

Recycling involves the use of materials that otherwise would become waste by turning them into valuable resources (Haas et al., 2015). Solid waste recycling also involves solid waste reuse which consists of waste items recovered to be used again, perhaps after some cleaning and refurbishing. Reuse materials and products save energy and water, reduces pollution, and lessens society's consumption of natural resources compared with the use of single application products and materials (Medina, 2008). The world best practices in sold management entail that, a great deal of recycling occurs before the solid waste reaches the landfill (Liu et al., 2015).

Another form of recycling is composting, the controlled aerobic biological decomposition of organic matter, such as food scraps and plant matter, into humus, a soil-like material (Shilev et al., 2007). Compost works as a normal fertiliser by supplying natural nutrients to the soil, swelling favourable soil organisms, and suppressing certain plant diseases, thereby reducing the need for chemical fertilisers and pesticides in landscaping and agricultural activities. Organic materials often comprise a large portion of the solid waste stream. Composting can be particularly helpful to communities managing their waste and thus reduce greenhouse gas emissions (Okot-Okumu, 2012). 
Apart from recycling being an important solid waste reduction and management strategy, it is also a way to decrease resource output, as using recycled material means reducing the number of new resources needed to manufacture a new product. The objectives of recycling are to save resources as well as reduce the environmental impact of waste.

\subsection{Solid waste recycling in Abuja, Nigeria}

Solid waste management in Nigeria has remained the sole duty of local government areas. Nigeria's Constitution of 1999, precisely the fourth schedule gives the task of maintenance and provision of sewage and refuse disposal to the local government areas (Onu et al., 2012). At present, there is no strategy or formal recycling programmes for the city of Abuja and no material recovery facility exists in the city.

Furthermore, presently only a negligible percentage of the municipal waste stream in Abuja is recovered through the recycling activities by the informal entrepreneurs. Consequently, materials recycling activities throughout the municipality are limited to household reuse and scavenging activities of the urban poor (Momodu et al., 2011; Ofobruku et al., 2016). The poor solid waste resource recovery implies that nearly the entire waste stream from the city has to be disposed of at dump sites. Current waste disposal methods in the city are limited to burning and open dumping since there is no engineer or sanitary landfills within the city. All the waste collected is taken to the Gosa solid waste dump site in the Idu Industrial Layout for disposal.

The Abuja Environment Protection Board (AEPB) has no formal recycling programme or strategy for the city of Abuja and no other material recovery facility exists in the city (Ofobruku and Ezeah, 2019). This shows there is a great opportunity for entrepreneurial involvement in solid waste management in the federal capital territory. The noticeable practices of solid wastes recycling in Abuja, Nigeria is that households in low-income areas reuse plastics, bottles, paper, cardboard and cans items for domestic purposes. These materials are disposed of only when they are no longer of any use to their owners while in other parts of the Abuja city that are of high income neighbourhoods, informer entrepreneurs directly take out valuable items such as metals, paper, and plastics from refuse bins/dumps or buy them from their owners for resale (Ofobruku and Ezeah, 2019).

\subsection{Sustainability of solid waste management}

The inability of any nation to reverse the downgrading of her natural, human and manufactured capitals will create an unsustainable economy; the consequence will be a decline in the economy activities (Oka, 2017). Therefore, environmental justice theory demands that the recognition of all human values depend on a healthy social, economic and ecological context, where all existing things have value independently (Brennan, 2002; Gladwin et al., 1995).

Sustainable development was first popularised globally in a report published by the World Commission on Environment and Development in 1987. Sustainable development from the report implies the type of development which emphasizes the meeting of consumptions needs of the present-day without jeopardising the capability of future generations to meet up with their own needs (Brundtland, 1987). The concept of sustainability represents the hierarchy of preferred options for sustainable management of solid waste in most develop nations and puts waste reduction and waste recycling practices as the most preferred elements in the solid waste hierarchy (Permana et al., 2015).

Solid waste recycling encompasses the technique of transforming solid waste materials into reusable resources to avoid wastage of materials that are still valuable. Solid waste recycling also reduces the depletion of the finite natural raw resources and energy consumption, as well as averting pollution by reducing the necessity for "orthodox" solid waste disposal. Therefore, solid waste recycling is an essential component of sustainable solid waste management.

\subsection{Nigerian performance in the Millennium Development Goal Seven and achieving United Nation Sustainable Development Goal Six}

Nigeria demonstrates the lingering solid waste management challenge dominant in several Sub Saharan African nations, as it contends with the problem of unsustainable solid waste management practices, a consequent of the existing overbearing growth rates of the population put at $2.9 \%$ per annum (Sridhar and Hammed, 2017). More so, there exist diverse data on solid waste generation and recycles in Nigeria owing to clumsy information management (Oleribe and Taylor-Robinson, 2016). Furthermore, Ezeah (2010) affirms that approximately $60 \%$ of Municipal Solid Waste (MSW) samples from Abuja were found to be biodegradable and recycle materials. With the high did percentage of biodegradable solid waste materials found in Abuja, sadly it is only the informal entrepreneurs that are presently the sole form of recycling available in the city accounting for approximately $3 \%$ of recycling rate and providing gainful employment to a significant 
number of Abuja residents (Ezeah, 2010), this implies that $97 \%$ of biodegradable solid waste from Abuja is unaccounted for. The sustainability program for solid waste management in Nigeria today not only expresses challenges but also opens up important opportunities for entrepreneurial activities.

The Millennium Development Goals (MDGs) was professed to be the world major promises for human wellbeing, particularly for the third world nations as a touchstone for achieving sustainable development, the specified time limit was 2015 (Way, 2015). It represents a pool of developmental objectives and targeted at attempting to achieve sustainable development through universal partnership. The MDGs were instituted by the United Nations, based on a succession of consultation and meetings held at numerous international fora. Worthy of note is MDG 7 which emphasises the guaranteeing of environmental sustainability (Giwa et al., 2016). Nigeria as an affiliate of the international committee of states represents a fragment of the worldwide nations that competed to achieve the MDGs. Nigeria attempting to achieve the MDGs necessitated the domestication of the MDG objectives by the establishment of the VISION 20:20:20, which was tailored within the structure of MDGs to function as a dynamic influence for attaining sustainable development.

At the end of the MDG period in 2015, Nigeria however, had a number of unsupported claims in that the nation achieved most of the goals (Akosile, 2015). The claims did not tally with situations on the ground as Nigeria was reported to be among one of the nations with the lowest numbers of children sleeping under the mosquito nets, in a comparison of surveys among nations of the world (Way, 2015). This was not unanticipated, Nigeria, like most sub-Saharan African nations, has failed to meet up with most of the MDG targets due to political and systemic challenges (Sachs and McArthur, 2005). The review of the MDGs in Nigeria in 2014 concluded that Nigeria would not attain the MDG targets by the end of 2015 (Olabode et al., 2014).

The major issue here is why Nigeria did not evidently meet up with the MDG objectives especially the MDG 7, this is critical, as the success of the recently flagged up Sustainable Development Goals (SDGs) especially goal six by the UN MDGs ought to benefit from the MDG experience so as to make the SDGs a success. In the studies carried out by several scholars on the MDGs, they identified the lack of human capacity for implementation, inadequate and unreliable data systems, inadequate funding and endemic corruption as the challenges faced by MDGs in Nigeria
(Ajiye, 2014; Meyer-Ohlendorf et al., 2014; Oleribe and Taylor-Robinson, 2016). The absence of true and validated baseline data since Nigerian independence has made the basis for most calculations and projections very faulty. MDGs did not succeed in Nigeria based on lack of accurate tangible baseline data with which to compare progress.

Consequently, going forward from the perspective of Sustainable Development Goals (SDGs 2030) agenda must benefit from lessons learned in the MDGs program. It is apparent that validated data are required for the success of the SDGs. It is essential to initiate analyses of field-based data and use such data to make significant predictions. It is imperative to have multidisciplinary studies that will have reliable external and internal validity. Nigeria governmental agencies also should publish periodically information for public usage, measurable process and evaluations are critical at key intervals and should be built into the implementation plans. This will support keeping the implementation of the SDGs program on course, and when deviations occur, corrections should be made early enough to achieve the goals as at 2030 . Nigeria must make constructive effort to achieve the SDGs come 2030.

\subsection{Entrepreneurial innovation on sustainable solid waste recycling capacity}

It has been debated that private sector involvement spearheaded by entrepreneurial could be the answer to the current challenge of solid waste management, while the government would only serve as a regulator. This is because entrepreneurs have a greater capacity for innovation in the various strata of the solid waste value chain (Al-Salem et al., 2009; Chong, 2006; Wang et al., 2011). The involvement of entrepreneurial activities could enable the municipalities to increase the rate of solid waste recycling and as such improve service delivery to the people. Entrepreneurial innovation in SWM could be found in solid waste activities such as reuse, as well as recycling. An entrepreneur could identify the business opportunity, undertake innovations, and finance the business from the solid waste product into economic good. The motivation to finance the business from the solid waste product is to make a profit while contributing to solving solid waste challenges.

It has been argued in Nigeria that private solid waste operators experienced difficulties because of weak relevant municipal policies and by-laws (Jean Bakole, 2017). Other studies also suggested a rethinking of the current approach for municipal solid waste management in developing countries with a view for municipalities to gradually 
improve the awareness levels of the community for the adoption of decentralized system in which entrepreneurs will have a key responsibility in solid waste management (Challcharoenwattana and Pharino, 2016; Kirama and Mayo, 2016, Ofobruku and Ezeah, 2019). It has also been argued that most investigations in solid waste management did not cover the key elements required for the involvement of private entrepreneurs, which has to do with entrepreneurial innovation, from solid waste management and how entrepreneurial capacities could best be applied to optimize efficiencies in solid waste recycling (Ahmed and McQuaid, 2005; Levi Jaksić et al., 2015; Mirchev and Dicheva, 2013; Mitra, 2012). Thus, Research hypothesis: $\mathrm{H}_{0}$ : There is a significant effect of entrepreneurial innovation on solid waste recycling in Abuja.

\section{Methods}

A trans-disciplinary research team was constituted by the authors, the team was put together to provide an accurate methodology that is a good fit for this type of study. The team looks at issues that border on entrepreneurial innovation and Sustainable Solid Waste recycles Capacity in Abuja, Nigeria. The numbers of professionals who volunteered their services were nine solid waste entrepreneurs, seven environmental consultants, six management researchers, eight solid waste employees with Abuja environment protection board and thirteen Abuja residents who are knowledgeable with the subject. The research team conducted an in-depth discussion for two hours for two days from $11^{\text {th }}$ to $12^{\text {th }}$ September 2017. The trans-disciplinary research team concluded and agreed that a survey design comprising the use of the questionnaire. Therefore, the study employed a survey design method involving questionnaires.

The population of this study was targeted at solid waste entrepreneurs in Abuja, the Nigerian federal capital. Abuja is made up of six area councils out of which four area councils (Abuja Municipal Area Council (AMAC); Bwari Area Council; Gwagwalada Area Council; and Kuje Area Council) were systematically selected for this study. These selected councils have the same unique experience in Solid Waste Management due to population pressure triggered by rapid urbanisation.

The population of this study was limited to solid waste entrepreneurs operating in the four area councils, duly registered with the Scavenger's Association (SA) and Abuja Environmental Protection Board (AEPB). Based on the data provided by Scavenger's Association (SA) and Abuja Environmental Protection Board (AEPB), the population for this study were one thousand, one hundred and forty-four (1144) solid waste entrepreneurs, Table 1 shows the breakdown of the population and sample size. A sample size calculation provided by Bartlett et al. (2001) was utilised, at a confidence level of $95 \%$ (Eq. (1)):

$n=\frac{z^{2} \times p \times q+e^{2}}{e^{2}+\left(z^{2} \times p \times q / N\right)}$,

substituting in the formula (Eq. (1)):

$$
n=\frac{\left(1.96^{2} \times 0.6 \times 0.4\right)+0.04^{2}}{0.04^{2}+\left(1.96^{2} \times 0.6 \times 0.4 / 1144\right)},
$$

sample size for solid waste entrepreneur $=384$.

Therefore, a sample size of 384 was calculated for the responses from the solid waste entrepreneur. Furthermore, the proportionate stratified sampling method was used to allocate questionnaire to the respondents, so as to provide a fair representation to each of the designated segment. Thus Eq. (2) is:

$$
Q=A / N \times n / 1 \text {. }
$$

\subsection{Instrument description and method of data collection}

Permission and ethical clearance for the study was obtained from the Abuja environmental protection Board. The total of 384 questionnaires were administered to the respondents by researcher through the use of the door to door self-administered questionnaire consisting of closed ended questions. 378 valid questionnaires were obtained, representing a response rate of $98 \%$. The survey was conducted between October $3^{\text {th }}$ and November $3^{\text {rd }}$, 2017. The questionnaire was designed to measure participants' notion of entrepreneurial innovation and sustainable solid waste recycling. Likert scales ranging from 1 (strongly disagree) to 5 (strongly agree) were employed for each item. The constructs for this study were adapted from previous studies on entrepreneurial innovation and solid waste recycle (Omar et al., 2017; Sigilai et al., 2017).

Table 1 The population and sample size

\begin{tabular}{lccc}
\hline S/N & Area & $\begin{array}{c}\text { Population } \\
\text { Solid Waste } \\
\text { Entrepreneur }\end{array}$ & Sample size \\
\hline 1. & AMAC & 553 & 185 \\
2. & KUJE & 160 & 54 \\
3. & GWAGW ALADA & 220 & 74 \\
4. & BWARI & 211 & 71 \\
5. & TOTAL & 1144 & 384 \\
\hline
\end{tabular}




\subsection{Validity of the instrument}

Content validity of the instrument was carried out using Content Validity Ratio (CVR) computation formula given as $\mathrm{CVR}=n \times e-n / 2 / n / 2$ (Thatcher, 2010), where $n$ is the total number of experts, ne is a number of experts regarding the item as essential. This resulted from the analysis of the opinions of twenty-one experts (six experts from the Abuja environmental protection board, three professors from the University of Nigeria, six entrepreneurial consultants and six, environmental consultants) who are experts in the field under investigation scrutinised the instrument on item by item basis to ensure that content of the instrument adequately represents the property under investigation and that they are also in line with the hypothesis of the study, yielded a content validity ratio of 0.79 which is appropriate for the study (Thatcher, 2010). The reliability of the instrument was determined through the use of pilot study; seventy-three of the questionnaires were pre-tested before the final fieldwork. These were sent with the support of the Scavenger's Association (SA) and Abuja Environmental Protection Board (AEPB), who are directly connected with the research population to stimulate their involvement in the study. There was a covering letter attached to the questionnaire guaranteeing the confidentiality of answers and declaring the purpose of the research. The reliability of responses was checked using Cronbach Coefficient Alpha, the result of the pilot test of the instrument showed that the reliability coefficient of the questionnaire yielded 0.81, thus indicating that the instrument is reliable. This means that the questionnaire was reliable enough for the conduct of this research, as Creswell (2014) and Pallant (2010) opined that Cronbach Alpha statistic of $0.7 \%$ and above imply that the data is reliable.

\subsection{Statistical techniques and model}

Given that this is a quantitative type research, the objectives of using the statistical models are:

1. to understand the characteristics of the variables, and

2. to make predictions on the dependence relations between them, validating the results (Hair et al., 2010).

An appropriate means to verify the hypothesis that the greater the innovation of different types that can be applied by entrepreneurs the greater the probability and the chances for an increase in recycling capability.

Innovation was measured with a three-dimensional scale:

1. Product/service innovation, which concerns the introduction or modification of new or improved products.
2. Process innovation that refers to introducing new or improved processes.

3. System innovation, related to the introduction of changes in the marketing structure of the entrepreneurs. The scale was used in previous research by (Gálvez Albarracín and García Pèrez de Lema, 2012; Martínez Serna et al., 2016) with consistent and reliable results.

The fact that the independent variable (entrepreneurial innovation) at the end determines the possibility of improvement in another variable (solid waste recycling), the linear regression model is appropriate (Hair et al., 1999; Miranda et al., 2018). Therefore, linear regression was used to analyse data generated so as to establish any relationships between the variables. The linear regression model assumes that there is a linear, or "straight line", relationship between the dependent variable and each predictor. This relationship is described in the formula (Eq. (3)) for the hypothesis.

$\mathrm{SWR}=\beta_{0}+\beta_{1} \times \mathrm{EI}+\mu_{1}$

SWR $=$ Solid Waste Recycling

$\mathrm{EI}=$ Entrepreneurial Innovation

$\beta_{0}=$ The interceptor autonomous parameter estimate

$\beta_{1}=$ the slope of the coefficients of the independent variables to be determined

$\mu=$ error term.

\section{Result of data analysis}

Innovativeness, as used in the study, refers to the Product/ service innovation, which concerns the introduction or modification of recycling solid waste products. Process innovation refers to introducing new or improved processes in recycling solid waste product. System innovation, related to the introduction of changes in the marketing structure of the solid waste entrepreneurs. The research investigates if the increase in the level of entrepreneurial innovativeness will improve solid waste recycling.

From Table 2, it is observed that the majority of responses received from respondents indicate that they are ready to include innovation in solid waste recycling.

Table 2 Responses on entrepreneurial potentials

\begin{tabular}{lcccccc}
\hline Questions & SA & A & UD & D & SD & Total \\
\hline $\begin{array}{l}\text { product/service } \\
\text { innovation }\end{array}$ & 128 & 126 & 26 & 63 & 35 & 378 \\
$\begin{array}{l}\text { process innovation } \\
\text { system innovation }\end{array}$ & 80 & 137 & 24 & 69 & 68 & 378 \\
\hline
\end{tabular}


Where $\mathrm{SD}=$ strongly disagreed, $\mathrm{D}=$ disagreed, $\mathrm{UD}=$ undecided, $\mathrm{A}=$ agreed, $\mathrm{SA}=$ strongly agreed.

Table 3 presents respondents self-rating on entrepreneurial involvement in solid waste recycling, based on the key components, presented to them. Table 4 shows that a significant number of respondents agreed or strongly agreed that entrepreneurial innovation will improve solid waste recycling.

Research Hypothesis: There is significant effect of entrepreneurial innovation on solid waste recycling capacity in Abuja.

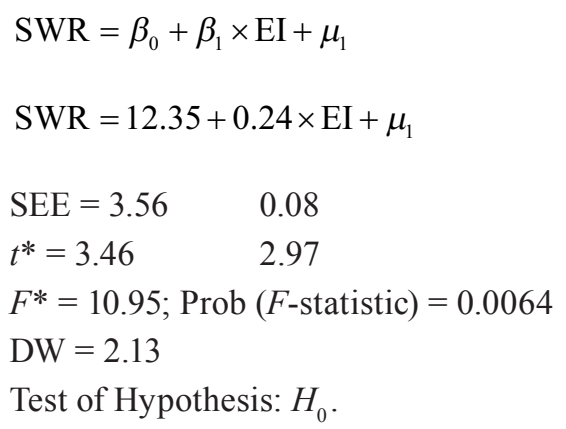

From the regression result in Table 4, the calculated $t$-value for entrepreneurial innovation is 2.97 is greater than the critical value of 1.96 . It falls in the rejection region and hence, we may reject the null hypothesis $\left(H_{0}\right)$. The conclusion here is that there is a positive and significant effect of entrepreneurial innovation on Solid Waste Recycling.

Table 3 Responses on solid waste recycling

\begin{tabular}{lcccccc}
\hline Questions & SA & A & UD & D & SD & Total \\
\hline $\begin{array}{l}\text { Modification of recycling } \\
\text { solid waste products will }\end{array}$ & 113 & 131 & 26 & 58 & 50 & 378 \\
$\begin{array}{l}\text { increase solid waste reuse } \\
\begin{array}{l}\text { Improved processes in } \\
\text { recycling solid waste }\end{array}\end{array}$ & & & & & & \\
$\begin{array}{l}\text { product will increase } \\
\text { waste items recovered to }\end{array}$ & 110 & 122 & 23 & 69 & 54 & 378 \\
be used again & & & & & \\
$\begin{array}{l}\text { Introduction of changes } \\
\text { in the marketing structure } \\
\text { of organic solid waste will } \\
\text { increase decomposition of } \\
\text { organic matter into humus }\end{array}$ & 106 & 116 & 20 & 71 & 65 & 378 \\
\hline
\end{tabular}

Table 4 Regression Result on EI and SWR

Stepwise Regression Analyses of entrepreneurial innovation on Outcome Variables

\begin{tabular}{lcccc}
\hline \multicolumn{4}{c}{ Dependent Variable: Solid Waste Recycling } \\
& $R_{2}=0.6342 ; F=10.95 ;$ Sig $=0.0064$ & \\
$\begin{array}{l}\text { Independent } \\
\text { Variables }\end{array}$ & Beta & $t$-value & $\begin{array}{c}\text { Pearson } \\
\text { Correlation }(r)\end{array}$ & $\begin{array}{c}\text { Probability } \\
\text { value }\end{array}$ \\
$\begin{array}{l}\text { entrepreneurial } \\
\text { innovation }\end{array}$ & 0.2 & 2.9 & 0.75189 & 0.0064 \\
\hline
\end{tabular}

Source: Authors Computation, 2017 (Eview-9.0)

\subsection{The ANOVA $F$-statistic}

The $F$-statistics which is used to examine the overall significance of regression model equally showed that the result is significant, as indicated by a high value of the $F$-statistic, 10.95 and it is significant at the 5.0 percent level. That is, the $F$-statistic value of 0.0064 is less than 0.05 .

\subsection{The ( $R$-square)}

The coefficient of determination ( $R$-square), used to measure the goodness of fit of the estimated model, indicates that the model is reasonably fit in prediction, that is, 63.42 percent change in solid waste recycling was due to entrepreneurial innovation, while 36.58 percent unaccounted variations were captured by the white noise error term. It shows that entrepreneurial innovation has a strong significant impact on the solid waste recycling.

\subsection{Discussion and implication}

It has been argued that private sector involvement spearheaded by entrepreneurs could be the answer to the solid waste challenge in Abuja, Nigeria because entrepreneurs have a better capacity to bring innovation into waste recycling. This research has investigated the influence of entrepreneurial innovation on waste recycling capacity in Abuja, Nigeria. Based on this result, we conclude that entrepreneurial innovation has a significant impact on solid waste recycling.

The study discloses that experience/policy on the ground presently in Abuja and Nigeria as a whole is that solid waste management is purely government business with little participation from the private sector. This has accounted for the unsustainability of solid waste management and poor level recycling of solid waste in Abuja, Nigeria leading the currently solid waste challenge in Abuja.

Based on results presented in Table 4, the significance value of 0.01 was less than 0.05 . Findings from this study, therefore, agree with earlier studies on this subject (Al-Salem et al., 2009; Chong, 2006). The finding of this study is unique in that among the various strata of the solid waste value chain, entrepreneurs' innovation can be employed to achieve sustainability in solid waste recycling in Abuja, Nigeria. Furthermore, the need to step up the involvement of entrepreneurs in solid waste recycling so as to achieve the SDGs 2030 becomes sacrosanct.

\section{Conclusion}

This investigation revealed that entrepreneurial innovation can be employed to improve the solid waste recycling capacity in Abuja, Nigeria. The findings of this 
study showed that sustainable solid waste management can be achieved in Abuja, Nigeria through entrepreneurial involvement. In the course of the investigation, the hypothesis tested, established the fact that increases in entrepreneurial innovation would have a corresponding increase in solid waste recycling capacity. The result shows that the entrepreneurial innovation has a significant effect on solid waste recycling capacity in Abuja, Nigeria.

Based on the findings from this study, the following recommendations are proposed:

- In order to sustainably resolve the perennial challenge of solid waste management in Abuja, Nigeria, the government should engage entrepreneurs more in solid waste management so as to sustainably achieve solid waste management in Abuja and Nigeria cities in general.

- The challenges of solid waste recycling in the Abuja, Nigeria is traceable to inadequate recycling practices; there is, therefore, the need to encourage greater involvement of entrepreneurial innovation so as to improve the current poor level of solid waste recycling. Furthermore, there is an urgent need to step up the involvement of entrepreneurs in solid waste recycling so as to achieve the SDGs 2030 becomes sacrosanct.

\subsection{Limitations}

The outcome of this study provides a contribution to literature in the area under investigation, especially related to entrepreneurial innovation in the context of improving the solid waste recycling capacity in Abuja, Nigeria. The contribution of this research verifies entrepreneurial innovation as it affects the improvement of solid waste recycling capacity.

Unexpectedly, the core limitation of this study was the paucity of literature in the involvement of entrepreneurial innovation on solid waste recycling in Abuja,

\section{References}

Acs, Z. J., Szerb, L. (2007) "Entrepreneurship, Economic Growth and Public Policy", Small Business Economics, 28(2), pp. 109-122. https://doi.org/10.1007/s11187-006-9012-3

Adebayo, P. O. (2015) "Impact of Government Entrepreneurial programmes on Youth SMEs Participation in Nigeria", Journal of Business and African Economy, 1(4), pp. 1-14.

Ahmed, A., McQuaid, R. W. (2005) "Entrepreneurship, management, and sustainable development", World Review of Entrepreneurship, Management and Sustainable Development (WREMSD), 1(1), pp. 6-30.

https://doi.org/10.1504/WREMSD.2005.007750
Nigeria. This circumstance has been attributed to the fact that solid waste management institutions are ineffective in Abuja, Nigeria; this has remained the experience in most capital cities in developing nations. There is also the practical difficulty for some respondents to answer questions in the questionnaire due to the fact that some solid waste entrepreneurs do not understand the English language. This limitation notwithstanding was overcome through the engagement of some of the locals to interpret in the Hausa language which is the common use dialect across north central Nigeria.

\section{Implications for future research}

In future investigations, samples should also be collected from city residents and more cities should be involved in one study. Financial and other restrictions also constrain this study to not ask some important questions on entrepreneurial innovation on solid waste recycling capacity in Abuja, Nigeria. The following subjects are therefore recommended for further research:

1. Effect of applied technology on the performance of solid waste management in Abuja, Nigeria.

2. Effect of eco-preneurship on sustainable solid waste management in Abuja, Nigeria.

\section{Acknowledgement}

The authors wish to thank the Abuja Environmental Protection Board (AEPB) for supporting this study. Professor, U.J.F. Ewurun, who is an expert in entrepreneurial development and Dr. C. Ezeah who is an accredited solid waste management consultant with the University of Wolverhampton, United Kingdom, for their constructive feedback on the earlier version of the manuscript.

Ajiye, S. (2014) "Achievements of Millennium Development Goals in Nigeria: A Critical Examination", International Affairs and Global Strategy, 25, pp. 24-36.

Akosile, A. (2015) "Nigeria Has Attained HIV, Maternal Mortality MDGs Targets Ahead of Deadline Asserts", THISDAY newspaper, [online] 09 August, 2015. Available at: http://www. thisdaylive.com/articles/nigeria-has-attainedhivmaternalmortality-mdgstargetsahead-of-deadline-fgasserts/216974/ [Accessed: 13 December 2017] 
Al-Salem, S. M., Lettieri, P., Baeyens, J. (2009) "Recycling and recovery routes of plastic solid waste (PSW): A review", Waste Management, 29(10), pp. 2625-2643.

https://doi.org/10.1016/j.wasman.2009.06.004

Åstebro, T., Michela, J. L. (2005) "Predictors of the Survival of Innovations", The Journal of Product Innovation Management, 22(4), pp. 322-335. https://doi.org/10.1111/j.0737-6782.2005.00129.x

Ayuba, K. A, Abd Manaf, L., Sabrina, A. H., Wan Nur Azmin, S. (2013) "Current Status of Municipal Solid Waste Management Practise in FCT Abuja", Research Journal of Environmental and Earth Sciences, 5(6), pp. 295-304.

Bartlett, J. E., Kotrlik, J. W., Higgins, C. C. (2001) "Organizational Research: Determining Appropriate Sample Size in Survey Research", Information Technology, Learning, and Performance Journal, 19(1), pp. 43-50.

Brennan, A. (2002) "Environmental Ethics", In: Zalta, E. N. (ed.) The Stanford Encyclopedia of Philosophy Metaphysics Research Lab, Stanford University, Stanford, CA, USA, pp. 1-12. [online] Available at: https://plato.stanford.edu/entries/ethicsenvironmental/ [Accessed: 28 January 2018]

Brundtland, G. H. (1987) "Our Common Future", World Commission on Environment and Development, United Nations General Assembly, New York, NY, USA, Rep. A/42/427. [online] Available at: https://sustainabledevelopment.un.org/content/documents/5987ourcommon-future.pdf [Accessed: 08 March 2019]

Challcharoenwattana, A., Pharino, C. (2016) "Wishing to finance a recycling program? Willingness-to-pay study for enhancing municipal solid waste recycling in urban settlements in Thailand", Habitat International, 51, pp. 23-30.

https://doi.org/10.1016/j.habitatint.2015.10.008

Chong, C. L. (2006) "Waste to Wealth, How it Works in Malaysia", Impak, 2, pp. 10-12.

Creswell, J. W. (2014) "Research Design: Qualitative, Quantitative, and Mixed Methods Approaches", Sage Publications, Inc., Thousand Oaks, CA, USA.

Elçi, Ş. (2007) "Innovation: Key to Development and Competition", Technopolis Group, Ankara, Turkey.

Emelumadu, O. F., Azubike, O. C., Nnebue, C. C., Azubike, N. F., Sidney-Nnebue, Q. N. (2016) "Practice, Pattern and Challenges of Solid Waste Management in Onitsha Metropolis, Nigeria", American Journal of Public Health Research, 4(1), pp. 16-22. https://doi.org/10.12691/ajphr-4-1-3

Ezeah, C. (2010) "Analysis of Barriers and Success Factors Affecting Sustainable Municipal Solid Waste Management in Abuja", $\mathrm{PhD}$ thesis, University of Wolverhampton.

Ezeah, C., Roberts, C. L. (2014) "Waste governance agenda in Nigerian cities: A comparative analysis", Habitat International, 41, pp. 121-128. https://doi.org/10.1016/j.habitatint.2013.07.007

Federal Government of Nigeria (2012) "The Transformation Agenda 2011-2015: Summary of Federal Government's Key Priority Policies, Programs and Projects", National Planning Commission, Abuja, Nigeria. [online] Available at: https://nairametrics.com/ wp-content/uploads/2013/03/Transformation-agenda-2011-2015. pdf [Accessed: 14 January 2018]
Gálvez Albarracín, E. J., García Peréz de Lema, D. (2012) "Impact of innovation on the performance of MSMEs: an empirical study in Colombia", Estudios Gerenciales, 28(122), pp. 11-27. https://doi.org/10.1016/S0123-5923(12)70191-2

Giwa, S. O., Nwaokocha, C. N., Layeni, A. T. (2016) "Assessment of Millennium Development Goal 7 in the Niger Delta Region of Nigeria via Emissions Inventory of Flared Gas", Nigerian Journal of Technology (NIJOTECH), 35(2), pp. 349-359.

https://doi.org/10.4314/njt.v35i2.16

Gladwin, T. N., Kennelly, J. J., Krause, T. S. (1995) "Shifting Paradigms for Sustainable Development: Implications for Management Theory and Research", Academy of Management Review, 20(4), pp. 874-907.

Haas, W., Krausmann, F., Wiedenhofer, D., Heinz, M. (2015) "How Circular is the Global Economy?: An Assessment of Material Flows, Waste Production, and Recycling in the European Union and the World in 2005", Journal of Industrial Ecology, 19(5), pp. 765-777. https://doi.org/10.1111/jiec.12244

Hair, J. F., Anderson, R. E., Tatham, R. L., Black, W. C. (1999) "Multivariate data analysis", Prentice-Hall International, Upper Saddle River, NJ, USA.

Hair, J. F., Wolfinbarger, M. F., Oritinau, D. J., Bush, R. P. (2010) "Essentials of marketing research", McGraw-Hill, New York, NY, USA.

Igoni, A. H. Harry, I. S. K. (2017) "Environmental Crises in Governmentcontrolled Municipal Solid Waste Management in Rivers State, Nigeria", Journal of Environment and Earth Science, 7(3), pp. 38-50.

Jean Bakole, J. (2017) "UNIDO Tasks FG on Effective Waste Management", This Day, [online] 02 December 2017. Available at: https://www.thisdaylive.com/index.php/2017/12/02/unido-tasksfg-on-effective-waste-management/ [Accessed: 14 January 2018]

Julian, C. C., Ahmed, Z. U. (2012) "Factors impacting international entrepreneurship in Malaysia", Journal of Small Business and Enterprise Development, 19(2), pp. 229-245. https://doi.org/10.1108/14626001211223874

Kirama, A. Mayo, A. W. (2016) "Challenges and prospects of private sector participation in solid waste management in Dares Salaam City, Tanzania", Habitat International, 53, pp. 195-205. https://doi.org/10.1016/j.habitatint.2015.11.014

Levi Jaksić, M. L., Jovanović, M., Petković, J. (2015) "Technology Entrepreneurship in the Changing Business Environment A Triple Helix Performance Model", Amfiteatru Economic Journal, 17(38), pp. 422-440.

Liu, A., Ren, F., Lin, W. Y., Wang, J. Y. (2015) "A review of municipal solid waste environmental standards with a focus on incinerator residues", International Journal of Sustainable Built Environment, 4(2), pp. $165-188$. https://doi.org/10.1016/j.ijsbe.2015.11.002

Lunati, M. (2010) "SMEs, Entrepreneurship and Innovation", OECD Publishing, Paris, France, Rep. MENA-OECD WG 2.

Mane, A. V. (2015) "A Critical Overview of Legal Profile on Solid Waste Management in India", International Journal of Research in Chemistry and Environment, 5(1), pp. 1-16.

Martínez Serna, M. D. C., Vega Martínez, J. E., Vega Martínez, J. (2016) "The Impact of Learning Orientation on Innovation and Performance in SME's in Mexico", International Review of Management and Business Research, 5(1), pp. 48-64. 
Mbah, P. O., Nzeadibe, T. C. (2017) "Inclusive municipal solid waste management policy in Nigeria: engaging the informal economy in post2015 development agenda", Local Environment: The International Journal of Justice and Sustainability, 22(2), pp. 203-224. https://doi.org/10.1080/13549839.2016.1188062

Medina, M. (2008) "Supporting Community-Based Recycling Initiatives in Latin America and the Caribbean", Grassroots Development, 29(1), pp. 26-31.

McNeil, M., Kerwin M. (1998) "United Nations Development Programme, world bank water \& sanitation program-south Asia", Lessons for improving service delivery, Learnings from private \& non-formal sectors in solid waste management, UNDP-World Bank, Water \& Sanitation Program - South Asia, New Delhi, India, Rep. 9448. [online] Available at: https://www.wsp.org/sites/wsp/ files/publications/multi_page7.pdf [Accessed: 14 January 2018]

Meyer-Ohlendorf, N., Görlach, B., McFarland, K. (2014) "Towards Sustainable Development Goals: Working Paper", Working Paper No. 18/2014, Umweltbundesamt, Dessau-Roßlau, Germany. [online] Available at: https://www.ecologic.eu/sites/ files/publication/2014/towards_sdgs_uba-texte_18-2014_0.pdf [Accessed: 22 December 2017]

Mitra, J. (2012) "Entrepreneurship, Innovation and Regional Development: An Introduction", Routledge, London, UK. https://doi.org/10.4324/9780203813782

Miranda, J. O., Valenzuela Valenzuela, A., Navarrete Hinojosa, M. A. (2018) "Innovation for integration into supplier networks of multinational companies", Contaduría y Administración, 63(1), pp. 13-14.

Mirchev, A., Dicheva, V. (2013) "Technological Entrepreneurship of Small and Medium Business in the Republic of Bulgaria as a Factor for Sustainable Development", In: CBU International Conference on Integration and Innovation in Science and Education, Prague, Czech Republic, pp. 91-96.

https://doi.org/10.12955/cbup.v1.19

Moghavvemi, S., Mohd-Salleh, N. A. (2014) "Malaysian entrepreneurs propensity to use IT innovation", Journal of Enterprise Information Management, 27(2), pp. 139-157.

https://doi.org/10.1108/JEIM-05-2012-0026

Momodu, N. S., Dimuna, K. O., Dimuna, J. E. (2011) "Mitigating the Impact of Solid Wastes in Urban Centres in Nigeria", Journal of Human Ecology, 34(2), pp. 125-133. https://doi.org/10.1080/09709274.2011.11906377

Obia, A. E. (2016) "Emerging Nigerian Megacities and Sustainable Development: Case Study of Lagos and Abuja", Journal of Sustainable Development, 9(2), pp. 27-42. https://doi.org/10.5539/jsd.v9n2p27

Ofobruku, S. A., Ezeah, C. (2019) "Modelling the impact of entrepreneurial venture risk taking on solid waste collection capacity in Abuja, Nigeria", World Review of Entrepreneurship, Management and Sustainable Development (WREMSD), 15(5), pp. 644-660. https://doi.org/10.1504/WREMSD.2019.103535

Ofobruku, S. A., Okafor, C. N., Agbaeze, E. K., Obi-Anike, H. O. (2016) "Entrepreneurial Potentials of Solid Waste Management in the Federal Capital Territory Abuja, Nigeria", Nigerian Journal of Social Sciences, 12(2), pp. 47-61.
Oka, N. O. (2017) "The Conceptualisation of Sustainable Development: an Interdisciplinary Exploration of Its Extensity, Practicability and Veracities", Management of Sustainable Development Sibiu, 9(2), pp. 47-57.

https://oi.org/10.1515/msd-2017-0021

Olabode, K. T., Kayode, A. Y., Zaggi Yacham, H., Owonibi, E. (2014) "Millennium Development Goals (MDGs) in Nigeria: Issues and Problems", Global Journal of Human-Social Science: C, Sociology \& Culture, 14(5), pp. 42-53.

Okot-Okumu, J. (2012) "Solid waste management in African cities-East Africa", In: Marmolejo Rebellon, L. F. (ed.) Waste managementan integrated vision, InTech, Maastricht, Netherlands, pp. 3-20. https://doi.org/10.5772/50241

Oleribe, O. O., Taylor-Robinson, S. D. (2016) "Before Sustainable Development Goals (SDG): why Nigeria failed to achieve the Millennium Development Goals (MDGs)", The Pan African Medical Journal, 24(1), Article Number: 156. https://doi.org/10.11604/pamj.2016.24.156.8447

Omar, S., Othman, N. A., Jabar, J. (2017) "Effect of Eco-Innovation Practices on Sustainable Business Performance", Pertanika Journal of Science and Technology, 25, pp. 123-128.

Onu, B., Price, T., Surendran, S., Ebie, S. (2012) "Solid Waste Management: A Critique of Nigeria's Waste Management Policy", International Journal of Knowledge, Culture and Change Management, 11, pp. 373-399.

Pallant, J. (2010) "SPSS: Survival Manual: a step by step guide to data analysis using SPSS", Open University Press, Maidenhead, UK.

Permana, S. A., Towolioe, S., Abd Aziz, N., Ho, C. S. (2015) "Sustainable solid waste management practices and perceived cleanliness in a low-income city", Habitat International, 49, pp. 197-205. https://doi.org/10.1016/j.habitatint.2015.05.028

Palczynski, R. J. (2002) "Study on Solid Waste Management Options for Africa", AfDB Sustainable Development and Poverty Reduction Unit, Abidjan, Ivory Coast. [online] Available at: https://www.gcca.eu/sites/default/files/2019-11/2002\%20 African\%20Development $\% 20$ Bank\%20_\%20Solid\%20 Waste $\% 20$ Management $\% 200$ ptions $\% 20$ for $\% 20$ Africa.pdf [Accessed: 28 December 2017]

Sachs, J. D., McArthur, J. W. (2005) "The Millennium Project: a plan for meeting the Millennium Development Goals", Lancet, 365(9456), pp. 347-353. https://doi.org/10.1016/S0140-6736(05)17791-5

Schendel, D., Hitt, M. A. (2007) "Introduction to Volume 1", Strategic Entrepreneurship Journal, 1(1-2), pp. 1-6. https://doi.org/10.1002/sej.16

Shilev, S., Najdenov, M., Vancheva, V., Aladjadjiyan, A., (2007) "Composting of Food and Agricultural Wastes", In: Oreopoulou, V., Russ, W. (eds.) Utilization of By-Products and Treatment of Waste in the Food Industry, Springer, Boston, MA, USA, pp. 283-301. https://doi.org/10.1007/978-0-387-35766-9_15

Shirokova, G., Bogatyreva, K., Beliaeva, T., Puffer, S. (2016) "Entrepreneurial orientation and firm performance in different environmental settings: Contingency and configurational approaches", Journal of Small Business and Enterprise Development, 23(3), pp. 703-727. https://doi.org/10.1108/JSBED-09-2015-0132 
Shook, C. L., Bratianu, C. (2010) "Entrepreneurial intent in a transitional economy: an application of the theory of planned behaviour to Romanian students", International Entrepreneurship and Management Journal, 6(3), pp. 231-247.

https://doi.org/10.1007/s11365-008-0091-2

Short, J. C., Moss, T. W., Lumpkin, G. T. (2009) "Research in social entrepreneurship: past contributions and future opportunities", Strategic Entrepreneurship Journal, 3(2), pp. 161-194. https://doi.org/10.1002/sej.69

Sigilai, C. J., Osodo, P., Nyiva, M. (2017) "The influence of innovativeness and pro-activeness on the performance of private colleges in Eldoret town, Kenya", International Journal of Commerce and Management Research, 3(8), pp. 24-29.

Sridhar, M. K. C., Hammed, T. B. (2017) "Entrepreneurship and urban waste: African perspectives", In: Oyanta, A., Nzeadibe, C. (eds.) Dealing with Waste: Resources Recovery and Entrepreneurship Informal Sector Solid Waste Management in African Cities, Africa World Press, Trenton, NJ, USA, pp. 57-80.

Szirmai, A., Naudé, W., Goedhuys, M. (eds.) (2011) "Entrepreneurship, Innovation, and Economic Development", Oxford Scholarship Online, Oxford, UK.

https://doi.org/10.1093/acprof:oso/9780199596515.001.0001

Thatcher, R. W. (2010) "Validity and Reliability of Quantitative Electroencephalography (EEG)", Journal of Neurotherapy: Investigations in Neuromodulation, Neurofeedback and Applied Neuroscience, 14(2), pp. 122-152.

https://doi.org/10.1080/10874201003773500
Toma, S. G., Grigore, A. M., Marinescu, P. (2014) "Economic Development and Entrepreneurship", Procedia Economics and Finance, 8, pp. 436-443. https://doi.org/10.1016/S2212-5671(14)00111-7

Üçdogruk, Y. (2006) "Employment impact of product and process innovations in Turkey", Ege Academic Review, 6(1), pp. 87-99.

Umaru, I. G. (2015) "Human Waste Management and Ecoprenuership Development in Nigerias Big Cities", MSc thesis, Nasarawa State University.

Wang, H., He, J., Kim, Y., Kamata, T. (2011) "Municipal solid waste management in small towns: An economic analysis conducted in Yunnan, China", Policy Research, Working Paper No. WPS 5767, World Bank, Washington, DC, USA.

Wang, Y., Rajagopalan, N. (2015) "Alliance Capabilities: Review and Research Agenda", Journal of Management, 41(1), pp. 236-260. https://doi.org/10.1177/0149206314557157

Way, C. (2015) "The Millennium Development Goals Report", New York, NY, USA, Rep. 15-10147. [online] Available at: https://www.un.org/ millenniumgoals/2015_MDG_Report/pdf/MDG\%202015\%20 Summary\%20web_english.pdf [Accessed: 14 February 2019] 